\title{
ROLAND BARTHES E O ENSAIO ENQUANTO FICÇÃO DA CHINA
}

\author{
Laura Taddei Brandini
}

\section{BARTHES E O ENSAIO}

Roland Barthes (2002e, p. 429), ${ }^{1}$ em sua Aula Inaugural proferida no Collège de France em 1978, revisita sua trajetória intelectual e descreve sua obra nestes termos: "E se é verdade que por muito tempo quis inscrever meu trabalho no campo da ciência, literária, lexicológica e sociológica, é preciso reconhecer que só produzi ensaios, gênero ambíguo em que a escritura ${ }^{2}$ disputa espaço com a análise". ${ }^{3}$ A restrição impingida pelo termo "só", é clara: o ensaio, para Barthes, não parece ser suficientemente científico para conduzir alguém à instância acadêmica máxima na França. Pela razão que ele menciona, sua ambiguidade, ou, em outros termos, pela porosidade que lhe permite ser, ao mesmo tempo, obra literária e analítico-argumentativa.

\footnotetext{
${ }^{1}$ Todas as traduções são de responsabilidade da autora deste artigo, exceto quando são empregadas traduções brasileiras das obras citadas, devidamente identificadas nas "Referências", com os nomes dos tradutores.

${ }^{2}$ Escritura [écriture], para Barthes, é sinônimo de escrita literária. A noção, apesar de ter flutuado em sua obra adquirindo nuanças diferentes, nunca deixou de significar o produto do escritor, aquele para quem escrever é um verbo intransitivo, em oposição à escrevência, o produto do escrevente, aquele que escreve com uma finalidade outra, que não puramente a de escrever. Leyla Perrone-Moisés esmiúça a noção em Texto, crítica, escritura (2005).

3 "Et s'il est vrai que j'ai voulu longtemps inscrire mon travail dans le champ de la science, littéraire, lexicologique et sociologique, il me faut bien reconnaître que je n'ai produit que des essais, genre ambigu où l'écriture le dispute à l'analyse."
} 
E, no entanto, sua obra, essencialmente ensaística, acabou por abrirlhe as portas do Collège de France. Barthes (2002c) talvez não se desse conta da riqueza de sua literatura, intrinsecamente ligada a um gênero que lhe ofereceu terreno fértil para o exercício de sua escritura, para a prática intransitiva do verbo escrever, como ele mesmo estabelece no ensaio "Écrivains et écrivants" [Escritores e escreventes], de 1960, republicado posteriormente no volume Essais critiques [Ensaios críticos], em 1964.

Nesse texto, ele distingue a escrita dita literária, a escritura, da escrevência, a escrita que serve a um objetivo, que visa transmitir uma mensagem ou causar um efeito, ou que simplesmente remete a um referente. Ao contrário da escrevência, a escritura é pura, intransitiva, autorreferencial. Tal categorização baseia-se numa concepção marxista do sistema literário, opondo os "escreventes" ou autores subordinados a um sistema burguês, aos "escritores", autores livres de toda submissão às normas do sistema. Essa visão maniqueísta, contudo, não é ingênua, uma vez que Barthes admite o fato de que não existe um exercício puro da escritura ou da escrevência, um puro escritor ou um puro escrevente, mas que os autores se movem entre as duas funções, podendo ser escritores e escreventes a um só tempo.

Em "Escritores e escreventes", Barthes (2002c) cria, portanto, duas noções que, à primeira vista, parecem responder ao ímpeto classificatório estruturalista, mantendo a compreensão marxista de mundo que norteava suas reflexões (principalmente via Bertold Brecht) durante a década de 1950. Contudo, tendo em vista os deslocamentos de sua obra, observamos que essa categorização não foi desenvolvida enquanto divisão de funções e atividades, e que unicamente a noção de escritura teve um destino diferente. Esta se tornou termo-chave para Barthes: a escritura foi por ele perseguida desde seus primeiros escritos, como O grau zero da escrita, de 1953 (2000), e praticada sobretudo na década de 1970, ressignificada inicialmente através da noção de Texto para, mais tarde, acrescida de uma pitada de romanesco e sob o formato de uma obra fantasmada, ser chamada de Romance.

Os movimentos dessas noções tão caras a Barthes - escritura, Texto, Romance - estão diretamente relacionados à evolução do ensaio francês na segunda metade do século XX, culminando com a metamorfose do gênero, associando-o à escrita ficcional. Palco de tamanhas transformações, a prática ensaística de Barthes tem vasto espaço nos capítulos finais da 
história da evolução do ensaio na França, de Marielle Macé (2006), Le temps de l'essai [O tempo do ensaio], obra de referência sobre o tema.

Partindo de Montaigne e passando pela forma do ensaio no século XIX, a autora se detém sobre o gênero no século XX e adota, como início de seu percurso, o ensaio segundo os autores da Nouvelle Revue Française. Analisa as reflexões de Sartre sobre o gênero e sua ambição em "fazer literatura" sob forma de ensaio para, em seu último momento, que deságua nos dias atuais, atribuir a Barthes o papel de desenvolvedor do gênero, no imbricamento de discurso científico e ficção.

Esse momento tem suas raízes nos anos 1960, quando a linguística foi escolhida como ciência fundamental para toda e qualquer reflexão no âmbito das Humanidades, conduzindo ao questionamento de conceitos e valores e, consequentemente, a algumas redefinições. O exemplo que aqui interessa mencionar é o de texto, que sob a pluma de Barthes (2002b) adquiriu um sentido muito mais vasto em "De l'oeuvre au texte" [Da obra ao texto], de 1971, no qual ele opõe à concepção tradicional de obra literária na França da época, ainda muito devedora de princípios oriundos do século XIX, ligados à historiografia e ao conceito romântico de escrita literária sua compreensão de Texto, grafado com letra maiúscula, objeto plural e infinito, de onde emanam significações as mais diversas, construídas a cada ato de leitura. Um espírito libertário, portanto, governa o Texto, segundo Barthes, que substitui a noção de autor pela de leitor, ${ }^{4}$ abraçando, com esse gesto, a multiplicidade de objetos-Textos que ela pode abarcar.

Nesse quadro de contestações teóricas e busca de maior liberdade é que Marielle Macé (2006, p. 226) situa o ápice do ensaio no século XX:

\begin{abstract}
Esse sucesso moderno da noção de ensaio deve, antes de mais nada, a sua solidariedade para com um lugar comum de nosso tempo: a hostilidade aos gêneros. Dentro de uma visão dos gêneros literários como gaiolas, sobrevivências, ruínas, o ensaio aparece (a mesmo título que o romance, mas em situação melhor, pois ainda não está massificado) como o antigênero por excelência, solução para as aporias classificatórias, forma fundamentalmente disponível em que entram as representações modernas da textualidade. É desse período que data a insistência no fato de o ensaio escapar aos gêneros, o que o valoriza duravelmente, mas também pode fazer com que perca sua firmeza categorial. 5
\end{abstract}

\footnotetext{
${ }^{4}$ Essa substituição, na realidade, já havia sido feita no célebre ensaio de 1968, "A morte do autor", de que "Da obra ao texto" é um desenvolvimento centrado na construção de uma nova noção, a de Texto. Cf. O rumor da língua (BARTHES, 1988a).

5 "Ce succès moderne de la notion d'essai tient avant tout à sa solidarité avec un lieu commun de notre temps: l'hostilité aux genres. À l'intérieur d'une vision des genres
} 
O estruturalismo já sendo passado no início dos anos 1970, o textualismo, com o Texto barthesiano à frente, não poderia mais suportar normas, regras, fronteiras, categorias... O "antigênero por excelência" se tornou a opção formal da transgressão, caindo muito bem a Barthes, como Macé (2006, p. 227) escreve, mais adiante:

Claro que Barthes é um dos pais da subversão dos gêneros e do triunfo do texto, que tornaram possível essa ideologização do ensaio, mas que sem dúvida são somente o ponto de chegada ou de naturalização da evolução do gênero durante o século $[\ldots]{ }^{6}$

Para Barthes, a distinção entre ensaio científico e ensaio literário não tem mais lugar desde 1963, com “Qu'est-ce que la critique?" [Que é a crítica?], texto publicado também nos Essais critiques [Ensaios críticos], em 1964 (BARTHES, 2002f); em 1966, com Critique et vérité [Crítica e verdade] (2002a), desenvolve e reafirma sua convicção: a crítica literária é livre para escolher a linguagem que quiser para envolver seu objeto. Essa escritura, esse tecido de linguagem, esse Texto redefine o ensaio crítico, e este passa a designar muito mais um estilo de escrita do que a análise e a demonstração de fatos e argumentos. Anos mais tarde, na Leçon [Aula], Barthes (2002e, p. 435) reflete de forma genérica sobre as duas linguagens, a dita "científica", praticada pelos cientistas e intelectuais, e a "literária", dos escritores:

O paradigma que proponho aqui não segue a separação entre as funções; não visa colocar de um lado os cientistas, os pesquisadores, e de outro, os escritores, os ensaístas; ao contrário, sugere que a escritura se encontre em todo lugar onde as palavras têm sabor (saber e sabor têm, em latim, a mesma etimologia).7

\footnotetext{
littéraires comme cages, survivances, ruines, l'essai apparaît (au même titre que le roman mais presque mieux que lui, parce qu'il n'est pas encore massifié) comme l'anti-genre par excellence, solution aux apories classificatoires, forme fondamentalement disponible où s'engouffrent les représentations modernes de la textualité. C'est de cette période que date l'insistance sur l'échappée générique de l'essai, qui le valorise durablement mais peut aussi lui faire perdre sa fermeté catégorielle."

6 "Barthes est bien sûr l'un des pères de la subversion des genres et du triomphe du texte, qui ont rendu possible cette idéologisation de l'essai, mais qui ne sont sans doute que le point d'aboutissement ou de naturalisation de l'évolution du genre au cours du siècle [...]." 7 "Le paradigme que je propose ici ne suit pas le partage des fonctions; il ne vise pas à mettre d'un côté les savants, les chercheurs, et de l'autre les écrivains, les essaystes; il suggère au contraire que l'écriture se retrouve partout où les mots ont de la saveur (savoir et saveur ont en latin la même étymologie)."
} 
Tendo em vista tal distinção de práticas e funções, Macé (2006, p. 239) marca bem os dois tempos do ensaio, associados à atividade dos escritores: "A questão é nova, pois não havia nada de significativo em fazer de Valéry, Bataille ou Sartre autores; o lugar de nascimento e de pertencimento de sua prosa intelectual era suficiente para fazer deles escritores". ${ }^{8}$ Em outras palavras, não eram o estilo, as ideias, os temas, em suma, não era a escritura ou o Texto que os definia como escritores, mas seu status.

Ora, com a compreensão pós-moderna do ensaio enquanto Texto, a enunciação passa ao primeiro plano, e se faz a voz escrita do escritor. Macé enxerga tal passagem na própria obra barthesiana, em 1970, ano de publicação de $S / Z$ e do Império dos signos: no primeiro livro, a autora vê o apogeu e a porta de saída para o ensaio crítico à moda estruturalista, ainda bastante ligado ao discurso da ciência; no segundo, a porta de entrada para o ensaio ficcional, metalinguístico, no qual reina a enunciação do escritor, e as ideias e argumentos se mostram indiretamente.

Barthes se indaga sobre tal dicotomia em sua conferência de 1978, no Collège de France, intitulada "Durante muito tempo, fui dormir cedo", dedicada a Proust e à escrita de Em busca do tempo perdido. Para ele, assim como na narrativa proustiana há o lado da casa de Swann e o lado de Guermantes, a própria obra é estruturada em dois lados, "o lado do Ensaio (da Crítica) e o lado do Romance” (BARTHES, 1988b, p. 284). Tal constatação o conduz a repensar as formas da escrita nestes termos:

Farei notar que a hesitação de Proust, à qual, é normal, dá uma forma psicológica, corresponde a uma alternância estrutural: os dois "lados" entre os quais hesita são os dois termos de uma oposição posta em evidência por Jakobson: a da Metáfora e da Metonímia. A Metáfora suporta todo discurso que levanta a questão: "O que é? O que é que isso quer dizer?"; é a própria questão do Ensaio. A Metonímia, ao contrário, levanta outra questão: "De que isto que estou anunciando pode ser seguido? O que é que o episódio que estou a contar pode gerar"; é a questão do Romance (BARTHES, 1988b, p. 284).

A oposição primeiramente exposta por Barthes (1988b, p. 285) entre Ensaio e Romance, essencialmente baseada nas escritas metafórica e metonímica, leva-o a buscar uma alternativa conciliatória, "uma forma mista, incerta, hesitante, ao mesmo tempo romanesca e intelectual", que ele chamará de "terceira forma”, novo gênero capaz de aliar metáfora

8 "La question est neuve, car il n'y avait rien de significatif à faire de Valéry, de Bataille ou de Sartre des auteurs; le lieu de naissance et d'appartenance de leur prose intellectuelle suffisait à les faire écrivains.” 
e metonímia, cujo exemplo maior é Em busca do tempo perdido. É, portanto, sob a égide de Proust que Barthes repensa sua prática, sua vida: cansado de repetir as mesmas formas (artigos, aulas, conferências) e de variar unicamente os temas, o escritor busca uma Aventura, com letra maiúscula, no sentido de algo que pode acontecer, algo que lhe advenha; essa novidade tem, contudo, um nome antigo: Romance.

Na concepção de Barthes (1988b, p. 292), o Romance aciona o pathos como motor da leitura; reconstruir sua história teria implicações relevantes:

[...] porque seria necessário, para esboçá-la [uma história patética do Romance], aceitar pulverizar o "todo" do universo romanesco, não mais colocar a essência do livro na sua estrutura, mas, ao contrário, reconhecer que a obra comove, vive, germina, através de uma espécie de "arruinamento" que só deixa de pé certos momentos, os quais são, propriamente falando, os seus cumes, a leitura viva, concernida, só seguindo de certo modo uma linha de crista: os momentos de verdade são como os pontos de mais-valia do entrecho.

Não mais ver a obra literária como uma totalidade, mas enxergá-la por meio de seus pontos salientes, segundo os afetos do leitor, tal é a lição que Barthes aprende com Proust. Estamos nos domínios da Metonímia, essa figura de linguagem do indireto por excelência, que mostra uma parte e faz o leitor adivinhar o todo, expandindo na imaginação uma gama de acontecimentos. O romanesco, portanto, é um convite ao leitor a participar da criação de sentidos, uma provocação, uma insinuação dentro dessa forma híbrida composta pelo ensaio e pela ficção, nomeada Romance.

Se, em 1978, Barthes reflete sobre sua prática cotidiana de escritura e teoriza sobre a nova forma que gostaria que lhe "acontecesse", muito antes, no início dos anos 1970, ele a pratica, já a partir de $O$ império dos signos, como apontamos em acordo com Macé. Ele não era o único a adotar o ensaio ficcional, havia toda uma geração de intelectuais identificados à vanguarda que então experimentava os limites do Texto, ampliando significativamente a compreensão do conceito, como assinala Macé (2006, p. 248):

Dentro desse "momento ficcional", observaremos um outro deslocamento, que leva, de um uso teórico bastante vasto da noção de ficção, em que toda construção sistemática pode se definir como uma montagem, à entronização 
da ficção como valor existencial, ao desejo da fábula, a um verdadeiro gosto pelo romanesco. ${ }^{9}$

Nesses anos de defesa da escritura sob a forma de um textualismo fervente, a ficção se esparrama por terrenos mais vastos do que nunca, e o "gosto pelo romanesco" dá, portanto, nova vida ao ensaio. O autor, que no texto de 1978 buscava, numa nova forma de escritura, uma vita nuova, como as de Dante e de Michelet (BARTHES, 1988b), teorizava sobre uma prática corrente, que Macé (2006, p. 248) sintetiza como segue: "A ficção é inicialmente mobilizada como quadro de pensamento: fora da cultura retórica, o ensaio se define como uma ficção teórica, um discurso que manipula suas ideias como personagens e constrói sua pesquisa como uma aventura”. Para Barthes (2002d), "Não existe nenhum discurso que não seja uma Ficção", como ele mesmo afirma em texto publicado na Quinzaine Littéraire em janeiro de $1976,^{10}$ o que já evidencia suas convicções, apenas sistematizadas e colocadas em destaque pela releitura da obra de Proust.

A prática do ensaio como Romance ou, simplesmente, ficção, portanto, permeia a obra de Barthes a partir, pelo menos, dos anos 1970; o escritor lidera um movimento de questionamentos, reflexões e busca por novas formas literárias, capazes de melhor dar conta dos efeitos que os fatos e os argumentos provocam no autor e no leitor, instância, então, alçada ao centro do universo literário. O exercício dessa prática, todavia, pode se dar num contexto político particularmente hostil ao, para usar o termo do autor, "indireto" do Romance barthesiano; é o que veremos com a análise de "E então, a China?", de Barthes (2004).

\section{A CHINA COMO FICÇÃO}

Assim como são anos de efervescência no campo teórico, particularmente importantes para a redefinição do ensaio enquanto gênero, os anos 1970

\footnotetext{
9 “À l'intérieur de ce 'moment fictionnel' on observera un autre déplacement, qui mène d'un usage théorique très large de la notion de fiction, où toute construction systématique peut se définir comme forgerie, à l'investissement de la fiction comme valeur existentielle, au désir de fable, à un véritable goût de romanesque."

${ }^{10}$ Trata-se do prefácio não publicado para o livro dos gêmeos Igor e Grigori Bogdanov, Clefs pour la science-fiction [Chaves para a ficção científica], no qual Barthes faz brevemente o elogio da união entre ciência - sob a forma dos discursos científicos, como o da filosofia, da história, da psicanálise etc. - e a ficção, sob a tutela desta última, tal como ele expressa em seu título.
} 
também são turbulentos no plano político. As notícias que corriam sobre o cerceamento de direitos imposto pelo regime estalinista, alimentadas pelas parcas, porém preocupantes, informações sobre os campos de trabalho da Sibéria, colocavam em questão a própria ideologia marxista aplicada à prática, sob a forma de um regime. Como alternativa ao capitalismo, surgia então o maoísmo, apoiado na chamada "Revolução Cultural" de Mao Tsé-Tung, idealmente, e assim vista por muitos intelectuais, uma revolução socioeconômica por meio da cultura.

Nesse quadro, portanto, a China era vista com muita curiosidade e através do filtro de alguns livros, notadamente o de Maria-Antonietta Macciocchi (1971), De la Chine [Sobre a China] - sucesso de vendas e publicado na França sob os auspícios de Philippe Sollers pela editora Seuil (a mesma das obras de Barthes) -, que retrata um regime socialista de sucesso, num país caminhando a passos largos rumo à prosperidade e à igualdade. Em oposição, Simon Leys, pseudônimo de Pierre Ryckmans, igualmente em 1971 lançava Les habits neufs du président Mao [As roupas novas do presidente Mao], denunciando a ditadura opressora do Partido Comunista Chinês (PCC) que, nos campos cultural e socioeconômico, impunha suas leis baseadas na censura e nos privilégios para os altos membros da administração pública. Tanto Macciocchi quanto Leys conheciam bem a China, sua história e sua cultura, e tinham vivências no país, o que, à primeira vista, poderia credenciá-los para tratar do tema. A escolha não era fácil.

Não era fácil, mas precisava ser feita, sobretudo para os intelectuais que se agrupavam em torno de jornais e revistas, estandartes de tendências culturais e posições políticas. Tel Quel, importante revista de vanguarda literária, então comandada por Philippe Sollers, Julia Kristeva e Marcelin Pleynet, era inicialmente marxista, alinhada às diretrizes do Partido Comunista Francês (PCF). Todavia, por uma questão de policiamento intelectual - o PCF censurara o livro-propaganda de Macciocchi -, acrescida da decepção originada pelas denúncias sobre a prisão, em campos de trabalho, de intelectuais opositores a Stalin, em 1972 Tel Quel rompe com o PCF para adotar o maoísmo como posição política. Barthes, colaborador da revista e amigo de seus editores, grande admirador de Antonioni e influenciado pelo documentário sobre a China intitulado Chung Kuo, Cina, rodado em 1972 e exibido na França em setembro de 1973, demonstra grande interesse pelo país, sem, contudo, declarar-se maoísta. 
É nesse ambiente um tanto quanto delicado politicamente que uma comitiva de Tel Quel, composta por Sollers, Kristeva, Pleynet, Barthes e seu editor na Seuil, François Whal, consegue autorização da embaixada chinesa para passar quase um mês no país do presidente Mao (de 11 de abril a 4 de maio de 1974). Seguindo orientação das autoridades chinesas, a agência de viagens Luxingshe prepara o roteiro e providencia toda a logística de deslocamentos entre Pequim, Xangai, Nanquim, Luoyang e Sião. Inseparável da comitiva, na China, eram os dois guias-tradutores, ambos chamados Zhao, que intermediavam - e tornavam possíveis ou impossíveis - todas as atividades do grupo. Desse modo absolutamente mediado, a comitiva visitou fábricas, escolas, uma universidade, cidadezinhas, sítios históricos, museus, assistiu a espetáculos de música e de dança, a um jogo de vôlei, foi ao cinema, mas não foi atendida em seu pedido para conhecer uma Escola de 7 de Maio, as "escolas" de reeducação pelo trabalho, para onde eram enviados os intelectuais dissidentes.

Durante a viagem Barthes (2012) manteve a escrita de um diário, que em 2009 foi publicado sob o título de Cadernos da viagem à China, no qual anotou detalhadamente as atividades e, sobretudo, os discursos de elogio à Revolução Cultural a que os estrangeiros eram submetidos diariamente. A cada visita, em qualquer lugar, fosse um museu, um sítio arqueológico, uma escola ou uma fábrica, o responsável local do Partido recepcionava o grupo e desatava seu relatório de fatos e números elogioso ao regime. Barthes tomava nota da infinidade de dados, porcentagens e cifras que jorrava diante de si, observando que se constituíam em blocos de informação, rígidos, fechados em si mesmos, organizados segundo o talento do orador. Os discursos, portanto, eram sempre os mesmos, apenas dispostos de maneira diferente.

Apesar de terem feito uma viagem absolutamentevigiada e, em muitos momentos, até mesmo censurada, isenta de todo e qualquer contato com pessoas que não as designadas pelo Partido, ao voltar à França as opiniões dos membros da comitiva sobre a China foram bastante diversas. Por um lado, Sollers, Kristeva e Pleynet publicaram artigos elogiosos ao maoísmo em Tel Quel, que lançou um número especial sobre a China, no outono de 1974; Kristeva (1974) ainda escreveu um livro enaltecendo o papel das mulheres na sociedade chinesa, Des chinoises [Sobre as chinesas]. Por outro lado, Whal (1974a, b, c, d), no jornal Le Monde, publicou uma série de quatro artigos intitulada "La Chine sans utopie" [A China sem utopia], em que critica severamente o maoísmo, associando-o ao estalinismo 
ditatorial. Barthes, por sua vez, publicou, também no Le Monde, um breve ensaio, intitulado “E então, a China?", que causou mais impacto do que todos os textos de seus companheiros de viagem.

Publicado vinte dias depois do retornoà França, em 24 de maio de 1974, o breve ensaio de Barthes foi extremamente mal recebido. O emprego do advérbio "extremamente" não é fortuito, pois ele dá conta dessa recepção, feita de extremos: os defensores da China maoísta atacaram Barthes como se ele estivesse destruindo o último bastião do sonho socialista; os detratores de Mao Tsé-Tung atacaram o escritor pela ausência de crítica a um regime ditatorial e nada igualitário. $\mathrm{O}$ ensaio não foi visto nem como a favor, nem como contra o maoísmo, descontentando os dois lados. Mas do que, afinal, ele tratou?

Da China. Da China expurgada de seu "Texto político" (BARTHES, 2004, p. 186), na expressão barthesiana. Da China fora do espaço ideológico político, da China enquanto vivência pessoal, desejo de conhecimento e de contato com o estrangeiro - o chinês, do ponto de vista de Barthes. Pois "E então, a China?" coloca uma pergunta ampla, que o próprio escritor se faz, nos seus Cadernos da viagem à China (2012, p. 9), e cuja resposta ele oferece sob a forma de, no seu termo, uma alucinação (BARTHES, 2004, p. 190). Pois ele alucina a China, criando um Texto metonímico, dando a ver somente algumas partes de sua vivência no país, insinuando sensações por meio de cores, como, por exemplo, no trecho que segue:

Afora seus palácios antigos, seus cartazes, seus balés infantis e seu Primeiro de Maio, a China não é colorida. O campo (pelo menos o que vimos, que não é o da antiga pintura) é uniforme; não é rompido por nenhum objeto histórico (nem campanários, nem castelos); ao longe, dois búfalos cinzentos, um trator, plantações regulares, mas assimétricas, um grupo de trabalhadores de azul, mais nada. $\mathrm{O}$ resto, até o infinito, é bege (tingido de rosa) ou verde esmaecido (o trigo, o arroz); às vezes, mas sempre pálidos, tapetes de colza amarela ou daquela flor malva que serve, ao que parece, de adubo. Nenhuma mudança de paisagem (BARTHES, 2004, p. 184).

A referência à pintura, mesmo que por sua negação, coloca-nos na pista: no parágrafo citado, o escritor compõe pictoricamente uma paisagem camponesa na China. Pela negação da cor - "a China não é colorida" - ele introduz uma palheta de cores pálidas: tons cinzentos, azulados, de bege "(tingido de rosa)", de verde "esmaecido", de amarelo ou de malva, que não descrevem objetivamente uma parte do espaço chinês, tampouco oferecem uma visão realista. Como se as palavras fossem traços, Barthes sugere linhas que estruturam a paisagem - "uniforme", 
"plantações regulares, mas assimétricas", "tapetes de colza amarela" - e, como se as palavras também fossem pinceladas, enche de manchas sua tela, recriando a China que vivenciou, a sua China.

O mesmo se dá com o sabor do chá:

O chá verde é insípido; servido em todas as ocasiões, renovado regularmente em nossa xícara com tampa, parece que só existe para pontuar com um ritual tênue e suave as reuniões, as discussões, as viagens: de tempos em tempos, uns goles de chá, um cigarro fraco, e a fala assume algo de silencioso, de pacato (como nos parece ser o trabalho nas oficinas que visitamos) (BARTHES, 2004, p. 184).

Apesar de sem sabor, o chá é bebida constante, pois tem uma função social - "ritual" - a cumprir. Sua insipidez transborda da xícara atingindo as situações de que faz parte, fazendo delas "tênues" e "suaves", contaminando o cigarro, que é "fraco", chegando até à fala, que passa a ter "algo de silencioso, de pacato", para enfim, ser estendida ao trabalho nas oficinas. Todas as esferas da vida chinesa, dos compromissos sociais ao cigarro que se fuma solitariamente ou em grupo, da maneira de falar à de trabalhar, parecem ter seu ritmo ditado pela insipidez e seus correlatos, perfazendo, mais uma vez, não uma apreciação objetiva, mas criando uma sugestão de ambiente a partir de um sabor particular, talvez um não sabor, que Barthes experimentou.

Estamos, portanto, em pleno campo da "delicadeza, ou melhor ainda (arrisco a palavra, arriscando-me a retomá-la depois), o da insipidez", como Barthes (2004, p. 184) o define. Nesse espaço textual, não há análise ou argumentação, mas imagens parciais: um pedaço de paisagem, um gosto particular, mais adiante alguns corpos e umas parcas observações sobre o vestuário (aliás, insípido também), que instigam a imaginação do leitor. Eis aí a faísca de romanesco, a linha solta que o leitor é convidado a puxar para encontrar, em seu ato de leitura, a vivência do escritor na China. As cores, a uniformidade, os sabores chineses não podem ser analisados, questionados, descritos de uma forma realista, mas podem, somente, ser evidenciados, mostrados, nomeados, pois "Em suma, com poucas exceções, a China só oferece à leitura o seu Texto político” (p. 186), afirma o autor.

Em outras palavras, a única coisa que pode ser lida objetivamente na China é a mensagem política; o país, tal como Barthes (2004, pp. 182-183) o conheceu, situa-se fora da hermenêutica e, por isso, não pode oferecer respostas às perguntas que o escritor formula sobre a sexualidade, a mulher, 
a família, a moral, as ciências humanas, a linguística e a psiquiatria: "A China parece resistir a entregar esse sentido [que os ocidentais buscam decifrar a todo preço], não porque o esconda, porém porque, mais subversivamente [...], desfaz a constituição dos conceitos, dos temas, dos nomes [...]". Somente o Texto político é legível, suscitando duas interpretações: por um lado, uma leitura ingênua, como a de Macciocchi e a dos editores de Tel Quel, dirigida pela predisposição" em aceitar de bom grado a ideologia tal como foi transmitida pelo Partido; por outro, uma leitura crítica, como a de Leys e Whal, que, embora desiludida, enxergava a total incoerência entre discurso - fazer uma revolução socioeconômica por meio da cultura - e prática -, as desigualdades sociais acentuadas pelos privilégios restritos aos membros do Partido.

Em outubro de 1975, por ocasião da republicação de "E então, a China?" sob a forma de plaquete, pelo editor Christian Bourgois, Barthes (2004, p. 189) acrescenta uma nota em que acusa as reações negativas ao ensaio e procura explicitar sua escolha em não tratar de política:

Sobre a China, imenso objeto e, para muitos, objeto candente, tentei produzir - essa era a minha verdade - um discurso que não fosse nem assertivo, nem negador, nem neutro: um comentário cujo tom fosse "no comment", um assentimento (modo de linguagem integrado numa ética e talvez numa estética), e não obrigatoriamente uma adesão ou uma recusa (modos que, estes sim, se integram numa razão ou numa fé).

Ao se recusar a ler o Texto político chinês e, consequentemente, não aceitar esses dois caminhos de leitura, o da "adesão" e o da "recusa", Barthes propõe, sob a forma de seu curto ensaio, uma terceira via, uma terceira forma, talvez a única capaz de dar conta plenamente da sua China: a escrita de um texto alucinado.

Ao criar uma doce alucinação da China como objeto situado fora da cor viva, do sabor forte e do sentido brutal [...], queria ligar num só movimento o infinito (materno?) do próprio objeto, essa maneira inaudita que a China teve, a meu ver, de extravasar o sentido, plácida e pujantemente, e o direito a um discurso especial: o de uma deriva ligeira, ou ainda de uma vontade de silêncio - de "sabedoria", talvez, entendendo-se esta palavra mais em sentido taoísta que

\footnotetext{
${ }^{\text {"1 }}$ Macciocchi militou pelo Partido Comunista Italiano desde os vinte anos de idade, tendo sido eleita deputada pela legenda; mais tarde, adotou o maoísmo como credo, na busca de uma postura antistalinista. Sollers, Kristeva e Pleynet interessavam-se pela cultura, história e língua chinesas muito antes de adotarem oficialmente o maoísmo como posição política para Tel Quel. Todos estavam, portanto, dispostos a abraçar a doutrina política de Mao Tsé-Tung.
} 
estoico ("O Tao perfeito não oferece dificuldade, a não ser por evitar escolher... Não se oponha ao mundo sensorial... O sábio não luta”) (BARTHES, 2004, pp. 189-190).

Essa alucinação é fruto da escolha do escritor, que, em seu ensaio, "num só movimento", pretendeu associar seu objeto, "infinito", a um "discurso especial". Ou seja, a recriação escritural da China de Barthes exigia um tipo de texto novo, diferente do Texto político, o único "autorizado" na época. O escritor escolhe, portanto, "não lutar", adotando a postura sugerida pelo Tao, e aceitar o "mundo sensorial”, recriando-o a propósito da China.

Essa recriação é possível, numa forma breve, somente com o ensaio, então fortemente identificado à ficção. O próprio Barthes (apud MACÉ, 2006, p. 211), um ano mais tarde, em Roland Barthes por Roland Barthes, explica sua ampla compreensão desse gênero:

Assim, todo ensaio repousa, talvez, sobre uma visão dos objetos intelectuais.

[...] Com as coisas intelectuais, fazemos ao mesmo tempo teoria, combate crítico e prazer; submetemos os objetos de saber e de dissertação - como em toda arte - não mais a uma instância de verdade, mas a um pensamento dos efeitos. ${ }^{12}$

Novamente a teoria, em Barthes, é posterior à prática, pois "E então, a China?” se encaixa com perfeição em sua reflexão acima citada. Espaço de experiências artísticas, o ensaio, para ele, deve ter por base uma "visão dos objetos intelectuais", tal como acontece com a China: uma visão enfumaçada, sem tanta nitidez dados os tons das cores, dos gostos, dos sons... Uma alucinação, como a visão de uma paisagem longínqua ou irreal, seria a única demonstração possível da China, uma vez que, para ele, a representação não é concebível. Tratando das forças da literatura na Aula, ele pontua:

\begin{abstract}
A segunda força da literatura é sua força de representação. Desde os tempos antigos até as tentativas da vanguarda, a literatura busca representar alguma coisa. O quê? Direi brutalmente: o real. O real não é representável, e é porque os homens querem representá-lo sem parar, por meio das palavras, que há uma história da literatura. Que o real não seja representável - mas
\end{abstract}

\footnotetext{
${ }_{12}$ "Tout essai repose ainsi, peut-être, sur une vision des objets intellectuels. [...] Avec les choses intellectuelles, nous faisons à la fois de la théorie, du combat critique et du plaisir; nous soumettons les objets de savoir et de dissertation - comme dans tout art - non plus à une instance de vérité, mais à une pensée des effets."
} 
somente demonstrável - pode ser dito de várias maneiras [...] (BARTHES, 2002e, p. 435). ${ }^{13}$

Barthes, então, busca demonstrar a China, não com argumentos, mas com imagens, porque a literatura "coloca em cena a linguagem, em lugar de, simplesmente, utilizá-la, ela despeja o saber na engrenagem da reflexividade infinita: por meio da escritura, o saber reflete sobre o saber sem cessar, segundo um discurso que não é mais epistemológico, mas dramático" (2002e, p. 434). ${ }^{14}$ A China é então dramatizada, posta em cena, enunciada, bem longe do discurso ensaístico tradicional, fundado numa epistemologia. Barthes (pp. 434-435) pondera, ainda na Aula, sobre esses dois discursos:

Segundo o discurso da ciência - ou segundo um certo discurso da ciência -, o saber é um enunciado; na escritura, ele é uma enunciação. $\mathrm{O}$ enunciado, objeto ordinário da linguística, é dado como o produto de uma ausência do enunciador. A enunciação, expondo o lugar e a energia do sujeito, até mesmo sua falta (que não é sua ausência), visa ao próprio real da linguagem; ela reconhece que a linguagem é um imenso halo de implicações, efeitos, repercussões, voltas, reviravoltas, saliências; ela assume fazer ouvir um sujeito ao mesmo tempo insistente e inobservável, desconhecido e, contudo, reconhecido segundo uma inquietante familiaridade: as palavras não são mais concebidas ilusoriamente, como simples instrumentos, são lançadas como projeções, explosões, vibrações, maquinários, sabores: a escritura faz do saber uma festa. ${ }^{15}$

${ }_{13}$ "La seconde force de la littérature, c'est sa force de représentation. Depuis les temps anciens jusqu'aux tentatives de l'avant-garde, la littérature s'affaire à représenter quelque chose. Quoi? Je dirai brutalement: le réel. Le réel n'est pas représentable, et c'est parce que les hommes veulent sans cesse le représenter par des mots, qu'il y a une histoire de la littérature. Que le réel ne soit pas représentable - mais seulement démontrable - peut être dit de plusieurs façons [...]."

${ }_{14}$ "[...] met en scène le langage, au lieu, simplement, de l'utiliser, elle engrène le savoir dans le rouage de la réflexivité infinie: à travers l'écriture, le savoir réfléchit sans cesse sur le savoir, selon un discours qui n'est plus épistémologique, mais dramatique."

15 "Selon le discours de la science - ou selon un certain discours de la science -, le savoir est un énoncé; dans l' écriture, il est une énonciation. L'énoncé, objet ordinaire de la linguistique, est donné comme le produit d'une absence de l'énonciateur. L'énonciation, elle, en exposant la place et l'énergie du sujet, voire son manque (qui n'est pas son absence), vise le réel même du langage; elle reconnaît que le langage est un immense halo d'implications, d'effets, de retentissements, de tours, de retours, de redans; elle assume de faire entendre un sujet à la fois insistant et irrepérable, inconnu et cependant reconnu selon une inquiétante familiarité: les mots ne sont plus conçus illusoirement comme de simples instruments, ils sont lancés comme des projections, des explosions, des vibrations, des machineries, des saveurs: l'écriture fait du savoir une fête." 
O pouco conhecimento que o autor adquiriu na China sobre o modo de vida das pessoas, suas cidades, sua cultura, sua história, é mostrado ao leitor sob a forma de uma festa chinesa, com os mesmos gostos, sons e vistas com os quais ele pôde saboreá-la durante a viagem. A China de Barthes (2004, pp. 184, 185, 188) é dramatizada principalmente pelo seu contrário, por tudo aquilo que ela não é: ela não se presta ao deciframento, "a China não é colorida", o campo "não é como o da antiga pintura", "não é rompido por nenhum objeto histórico", "não há moda nem cosméticos", "o corpo já não é para ser compreendido", "Ali o sentido é anulado", "um povo [...] circula, trabalha, toma seu chá ou faz sua ginástica solitária, sem teatro, sem barulho, sem pose, enfim sem histeria”. Tal profusão de negativas faz da China de Barthes (2004, p. 190) uma alucinação particular, negativa:

Essa alucinação negativa não é gratuita, pretende responder ao modo de
alucinação com que muitos ocidentais veem a China popular: um modo
dogmático, violentamente afirmativo/ negativo ou falsamente liberal. Não será
afinal a ideia banal do político achar que só pode chegar à linguagem na forma
de um discurso diretamente político? O intelectual (ou o escritor) não tem
lugar - ou esse lugar é apenas o Indireto: foi a essa utopia que tentei dar um
discurso afinado (musicalmente). Devemos amar a música, a chinesa também.

Nessa passagem, que é o parágrafo final do posfácio publicado na pequena edição de 1975, Barthes responde aos ataques que sofreu por não ter adotado um discurso esperado sobre a China, diretamente político, como os de seus colegas de viagem e de outros intelectuais que visitaram o país à época. O discurso do escritor é indireto, o que não significa que não haja discurso. A escritura dramatiza a epistemologia e a representação (no sentido teatral do termo) substitui a descrição. A ficção, na forma do ensaio, híbrida por conter indiretamente a escolha política de Barthes - a liberdade para não aceitar nenhum ponto de vista dogmático, a sabedoria do Tao em não ceder a nenhuma imposição ideológica -, é o lugar comum a tantas noções (escritura, Texto, Romance, demonstração, dramatização) que pululam pela obra barthesiana.

A respeito da noção de ficção que pouco a pouco se instalou no seio do ensaio, transformando-o, Macé (2006, p. 250) explica que a associação entre aquela e o gênero deve muito ao "amálgama constante estabelecido entre representação e ficção, entre construção e romance, e podemos concluir que hoje se tem uma banalização da noção de ficção nas ciências humanas [...]". Barthes (1988b, p. 293) contribuiu também para embaralhar essas duas noções, a de representação e a de ficção, quando, no já citado 
"Durante muito tempo, fui dormir cedo", escreveu: “[...] o Romance, sendo representação e não expressão”. A representação, portanto, para ele, é compreendida num sentido não realista, mas teatral, opondo-se à expressão, e é sinônimo de Romance, sua terceira forma, um híbrido de ensaio e de ficção. Sua alucinação da China deve então ser lida como uma representação enquanto Texto sensorial, que dá a ver uma parte e instiga a recriação do todo, como Macé (2006, p. 251) resume em relação ao ensaio ficcional: "A coleção de abstrações transportada pelo ensaio tende a se tornar um mundo povoado por elementos concretos, pelo menos é assim que o ensaísta quer representá-lo para si mesmo”.

Assim Barthes representa a China, recriando sua vivência no país por meio de elementos sensoriais e concretos - cores, gostos, cheiros, práticas. Seus leitores da época se enganaram de ensaio: procuravam uma análise política, e encontraram uma alucinação negativa. Não aceitaram o convite para a festa chinesa oferecida pela escritura barthesiana, recusaram o chá que lhes foi oferecido, não conseguiram desfrutar do Romance que se esgueira entre as perguntas sem resposta, não foram espectadores da dramatização da experiência da viagem, em suma, não tiveram olhos para ler a ficção chinesa de Barthes sob forma de ensaio.

\section{REFERÊNCIAS}

BARTHES, Roland. A morte do autor. In: O rumor da língua. Trad. Mario Laranjeira. São Paulo: Editora Brasiliense, 1988a, pp. 65-70.

BARTHES, Roland. Durante muito tempo, fui dormir cedo. In: O rumor da língua. Trad. Mario Laranjeira. São Paulo: Editora Brasiliense, 1988b, pp. 283-294.

BARTHES, Roland. S/Z. Trad. Léa Novaes. Rio de Janeiro: Nova Fronteira, 1992.

BARTHES, Roland. O grau zero da escrita seguido de Novos ensaios críticos. Trad. Mario Laranjeira. São Paulo: Martins Fontes, 2000.

BARTHES, Roland. Critique et vérité. In: Oeuvres complètes. Edição de Éric Marty. V. 2. Paris: Seuil, 2002a, pp. 759-801.

BARTHES, Roland. De l'oeuvre au texte. In: Oeuvres complètes. Edição de Éric Marty. V. 3. Paris: Seuil, 2002b, pp. 908-916.

BARTHES, Roland. Écrivains et écrivants. In: Essais critiques. Oeuvres complètes. Edição de Éric Marty. V. 2. Paris: Seuil, 2002c, pp. 403-410. 
BARTHES, Roland. Il n'existe aucun discours qui ne soit une fiction. In: Oeuvres complètes. Edição de Éric Marty. V. 4. Paris: Seuil, 2002d, pp. 937-939.

BARTHES, Roland. Leçon. In: Oeuvres complètes. Edição de Éric Marty. V. 5. Paris: Seuil, 2002e, pp. 429-446.

BARTHES, Roland. Qu'est-ce que la critique? In: Essais critiques. Oeuvres complètes. Edição de Éric Marty. V. 2. Paris: Seuil, 2002f, pp. 502-507.

BARTHES, Roland. E então, a China? In: Inéditos. V. 4 (Política). Organização de Leyla Perrone-Moisés. Trad. Ivone Castilho Benedetti. São Paulo: WMF Martins Fontes, 2004, pp. 182-19o.

BARTHES, Roland. O império dos signos. Trad. Leyla Perrone-Moisés. São Paulo: WMF Martins Fontes, 2007.

BARTHES, Roland. Cadernos da viagem à China. Trad. Ivone Castilho Benedetti. São Paulo: WMF Martins Fontes, 2012.

KRISTEVA, Julia. Des chinoises. Paris: Éditions des Femmes, 1974.

LEYS, Simon. Les habits neufs du président Mao. Paris: Éditions Champ Libre, 1971.

MACCIOCCHI, Maria-Antonietta. De la Chine. Paris: Seuil, 1971.

MACÉ, Marielle. Le temps de l'essai. Histoire d'un genre en France au XX $\mathrm{X}^{\mathrm{e}}$ siècle. Paris: Belin, 2006.

PERRONE-MOISÉS, Leyla. Texto, crítica, escritura. São Paulo: Martins Fontes, 2005[1975].

TEL QUEL, En Chine, Paris, n. 59, outono de 1974.

WHAL, François. La Chine sans utopie. I. Pi Lin Pi Kong. Le Monde, 15 de junho de 1974a pp. 1 e 7 .

WHAL, François. La Chine sans utopie. II. Tien An Men ou de l'explication avec le modèle soviétique. Le Monde, 17 de junho de 1974b, p. 4.

WHAL, François. La Chine sans utopie. III. Staline, ou l'ennemi principal, c'est le révisionnisme. Le Monde, 18 de junho de 1974c, p. 6.

WHAL, François. La Chine sans utopie. IV. Révolution culturelle ou occidentalisation? Le Monde, 19 de junho de 1974 d, p. 8. 